\title{
Etanercept in a therapeutic program for the treatment of rheumatoid arthritis and ankylosing spondylitis -7 years' personal experience
}

\author{
Etanercept $w$ programie terapeutycznym leczenia reumatoidalnego zapalenia stawów \\ i zesztywniającego zapalenia stawów kręgosłupa - 7-letnie doświadczenia własne
}

\author{
Maria Majdan, Zofia Kiełbik, Renata Seweryn \\ Chair and Department of Rheumatology and Connective Tissue Diseases, Medical University of Lublin \\ Katedra i Klinika Reumatologii i Układowych Chorób Tkanki Łącznej, Uniwersytet Medyczny w Lublinie
}

Key words: etanercept, rheumatoid arthritis, ankylosing spondylitis.

Stowa kluczowe: etanercept, reumatoidalne zapalenie stawów, zesztywniające zapalenie stawów kręgosłupa.

\section{Sum mary}

Aim of the study: To investigate the effectiveness and safety of etanercept (ETA) treatment in patients with active rheumatoid arthritis (RA) and ankylosing spondylitis (AS) enrolled in the national therapeutic program.

Material and methods: The study was conducted in 55 adult patients with active RA (DAS28 > 5.8) and 33 adult patients with active AS (BASDAI > 7) who were enrolled in the ETA national therapeutic program as a first (40 RA patients) or second (15 RA patients) line biological therapy. The period of observation of RA patients lasted from 3 months to 9 years, whereas in AS patients it lasted from 1 to 30 months. The safety; rate of long-term remissions and primary or secondary ineffectiveness of ETA treatment were analyzed.

Results: Permanent remission (over 12 months without biological therapy) occurred in a similar percentage of RA patients (5-9\%) and AS patients (3-9\%). There were 7 non-responders $(12.7 \%)$ to the initial treatment with ETA in a group of RA patients and $3(9 \%)$ in AS patients (NS). Secondary ineffectiveness of ETA therapy was observed in 19 (34.5\%) RA patients and in 2 (6.1\%) AS patients. Side effects (infections and allergic skin reactions) were relatively rare, mainly at the beginning of therapy.

Conclusions: We conclude that ETA treatment is a safe and effective form of therapy in patients with active, long-term RA previously treated with various DMARDs, and in patients with active form of AS. Primary ineffectiveness of ETA therapy is relatively rare in RA and AS patients. On the other hand, the secondary ineffectiveness of therapy in RA patients is the reason for its discontinuation in about onethird of patients after ca. 28 months of treatment.

\section{Streszczenie}

Cel pracy: Analiza przebiegu, skuteczności oraz bezpieczeństwa leczenia etanerceptem (ETA) grupy chorych na aktywne reumatoidalne zapalenie stawów (RZS) i zesztywniające zapalenie stawów kręgosłupa (ZZSK) przy istnieniu uwarunkowań związanych z realizacją programu terapeutycznego.

Materiat i metody: Retrospektywną oceną objęto przebieg leczenia w programie terapeutycznym 55 chorych na RZS i 33 chorych na ZZSK. $\mathrm{U}$ chorych na RZS ETA był stosowany jako terapia biologiczna pierwszego rzutu (40 osób) lub jako terapia kolejna (15 osób). Czas leczenia ETA chorych na RZS wynosit od 3 miesięcy do 9 lat, chorych na ZZSK od 1 do 30 miesięcy. Przeanalizowano częstość występowania długotrwałych remisji, pierwotnej nieskuteczności, wtórnej nieskuteczności oraz częstość występowania działań niepożądanych. Wyniki: Trwałą remisję choroby (bez leczenia biologicznego > 12 miesięcy) uzyskano u takiego samego odsetka chorych na RZS i ZZSK, tj. 9\%. Pierwotny brak odpowiedzi na leczenie (po 3 miesiącach stosowania terapii) odnotowano u 12,7\% chorych na RZS oraz 9\% chorych na ZZSK (różnica nieistotna statystycznie). Wtórny brak odpowiedzi na leczenie obserwowano u 35\% chorych na RZS - średnio po 28 miesiącach terapii oraz u 6\% chorych na ZZSK w okresie obserwacji do 30 miesięcy. Działania niepożądane (zmiany skórne i infekcje) występowały stosunkowo rzadko, głównie w początkowym okresie terapii. Wnioski: Etanercept jest bezpiecznym, skutecznym lekiem w terapii aktywnego RZS i ZZSK. Pierwotna nieskuteczność terapii ETA występuje stosunkowo rzadko, podobnie często u chorych na RZS i ZZSK. U ok. 1/3 chorych na RZS wtórna nieskuteczność terapii jest przyczyną przerwania leczenia, średnio po 28 miesiącach leczenia.

Address for correspondence:

prof. dr hab. n. med. Maria Majdan, Katedra i Klinika Reumatologii i Układowych Chorób Tkanki Łącznej UM, ul. Jaczewskiego 8,

20-950 Lublin, phone +48 8172447 90, fax +48 8174251 03, e-mail: maria.majdan@gmail.com 


\section{Introduction}

Etanercept (ETA - Enbrel) is a recombinant fusion protein comprising two distinct human proteins: the extracellular portion of the TNFR2/p75 receptor and the Fc fragment of human immunoglobulin G1. It is an analogue of the soluble TNF receptor TNF-R2. The soluble receptor binds with free TNF, lowering its concentration. Etanercept also possesses an affinity towards lymphotoxins. Thus, etanercept binds and neutralizes free TNF and lymphotoxins [1-3]. It displays lower immunogenicity than other chimeric proteins. The same dose of medication may be effective over longer periods of treatment [1-3]. Etanercept is registered for the treatment of rheumatoid arthritis (RA), juvenile idiopathic arthritis (JIA), ankylosing spondylitis (AS), psoriatic arthritis (PSA), and psoriasis [4].

In Poland, biological drugs available through state-funded therapeutic programs (TP) include etanercept, infliximab, adalimumab, and rituximab. The majority of patients have been treated with etanercept [5-7].

The aim of the study was to analyze the course, effectiveness and safety of long-term treatment using etanercept in a group of patients with RA and with AS in the presence of regulations governing the implementation of therapeutic programs.

\section{Material and methods}

The clinical analysis involved 88 patients; 55 patients with RA had undergone treatment using ETA in the period from 2005 to mid-2012 and 33 patients with AS were treated with ETA in the period from 2010 to mid-2012 (up to 30 months). Some subjects (40 patients $-72.7 \%$ ) had received a once weekly subcutaneous $50 \mathrm{mg}$ dose of ETA as initial therapy or as a subsequent therapy following nonresponse to a previous therapy (15 patients). The therapy was conducted subject to changing requirements for implementing therapeutic programs (TP), which determined the timing of disease activity evaluations and the duration of drug administration in the event of a patient achieving remission or low disease activity. During the course of subsequent appointments - their frequency being determined by the requirements of the therapeutic program - for patients with RA, the evaluation involved an assessment of the number of tender and swollen joints (out of 28 joints), the severity of pain and disease activity on a visual analogue scale (VAS) as well as an erythrocyte sedimentation rate (ESR) test. Rheumatoid arthritis activity was assessed based on the Disease Activity Score of 28 joints (Disease Activity Score 28 - DAS28) along with the ESR value. Remission was defined as DAS $28<2.6$, low disease activity as $2.6 \geq$ DAS $28 \leq 3.2$. In accordance with the guidelines of the therapeutic program, therapy was withdrawn upon achieving remission or low disease activity sustained over a period exceeding 6 months. Reintroduction of the medication that had produced the remission was possible in the event of an increase in DAS28 of 1.2 compared to the value obtained at the time of drug discontinuation, provided the DAS28 value was not lower than 3.2.

In patients with AS, disease activity was assessed based on spinal pain VAS and the Bath Ankylosing Spondylitis Disease Activity Index (BASDAI). Low disease activity was determined based on a BASDAl score of < 3.0. The therapeutic program also determined drug discontinuation in the event it was ineffective (RA patients who failed to achieve a 1.2 decrease in DAS28 after 3 months of treatment; patients who failed to achieve a decrease in their BASDAI score by $\geq 50 \%$ or by 2 units and a reduction of spinal pain VAS by $\geq 2 \mathrm{~cm}$ after 3 months of treatment) at the next scheduled clinical assessment. If the drug was ineffective in a patient with RA, an alternative biological drug could be used.

Patients with RA were eligible for ETA therapy if they fulfilled current Polish National Health Fund (Narodowy Fundusz Zdrowia - NFZ) TP criteria [7] which were: active stage of the disease (DAS28 > 5.1 measured twice, with a onemonth interval between assessments) and failure of treatment using $\geq 2$ traditional disease-modifying anti-rheumatic drugs (DMARDs), including the maximum tolerated dose of methotrexate (MTX), with each drug being administered over a period $\geq 6$ months. All the RA patients had undergone prior treatment with several DMARDs, including, in every case, MTX as well as sulfasalazine (SS), chloroquine (CQ), leflunomide (LEF), cyclosporine A (CSA), gold salts, and biological drugs: infliximab (IFX) (12 patients), rituximab (2 female patients), and adalimumab (1 male patient). Patients with AS were qualified for ETA therapy if they had active and severe disease (BASDAI $\geq 4$ and spinal VAS $\geq 4$ ), documented twice, with an interval $\geq 12$ weeks between assessments, in the absence of a satisfactory response to $\geq 2$ non-steroid antiinflammatory drugs (NSAIDs) [7].

\section{Results}

Patients with RA and AS treated with ETA in TPs were primarily patients who had previously undergone long-term treatment for their disease using DMARDs (RA) or NSAIDs (AS) (Table I). In the majority of cases, administration of the biological drug was initiated in a late-stage, chronic phase of active disease after failure to respond to prior treatment. Disease activity at the time of ETA therapy initiation, in the case of RA as well as AS, was high (Table II). Among the group of RA patients undergoing analysis were patients who had been treated with ETA for periods of between 3 months and 9 years - with interruptions for periods of remission when, in accordance with TP requirements, treatment was withdrawn. The mean duration of remission without ETA in RA patients was 6.4 months and was significantly longer than in patients with AS, who sustained 
Table I. Clinical characteristics of patients with rheumatoid arthritis and ankylosing spondylitis treated with etanercept

\begin{tabular}{|lcc|}
\hline Patients/Data & Rheumatoid arthritis & Ankylosing spondylitis \\
\hline Number of patients (F/M) & $55(49 / 6)$ & $33(7 / 26)$ \\
\hline Age (in years) $x \pm$ SD & $51.8 \pm 12.2(25-73)$ & $41.5 \pm 10.2(26-63)$ \\
\hline RF IgM & $34 / 55-61.8 \%$ & NA \\
ACPA & $37 / 55-67.3 \%$ & \\
RF IgM + ACPA & $27 / 55-49.1 \%$ & $30(90.1 \%)$ \\
\hline HLA-B27 positive & NA & NA \\
\hline Duration of DMARDs treatment prior & $x=8.3 \pm 6.2$ & $x=9.3 \pm 6.2$ \\
to ETA therapy (in years) & (from 2 to 18 years) & (from 4 to 24) \\
\hline Duration of NSAIDs treatment prior & NA & \\
to ETA therapy (in years) & & \\
\hline
\end{tabular}

$N A$ - not applicable; $x \pm S D$ - mean \pm standard deviation; RF IgM - IgM-class rheumatoid factor; ACPA - anti-citrullinated peptide antibodies; DMARDs - disease-modifying anti-rheumatic drugs; NSAIDs - non-steroid anti-inflammatory drugs

Table II. Results of treatment with etanercept (ETA) in patients with rheumatoid arthritis (RA) and ankylosing spondylitis (AS)

\begin{tabular}{|c|c|c|}
\hline Patients/Data & Rheumatoid arthritis & Ankylosing spondylitis \\
\hline $\begin{array}{l}\text { DAS28 } \\
\text { BASDAI } \\
\text { while on ETA }\end{array}$ & $\begin{array}{c}5.86 \pm 0.73(4.1-7.6) \\
-\end{array}$ & $\begin{array}{c}- \\
7.02 \pm 1.46(4.4-9.4)\end{array}$ \\
\hline $\begin{array}{l}\text { Duration of ETA therapy including intervals } \\
\text { for periods of remission }\end{array}$ & 3 months -9 years & 1-30 months \\
\hline $\begin{array}{l}\text { Remission } \\
>12 \text { months without ETA therapy }\end{array}$ & $\begin{array}{l}5 \text { patients }(9 \%) ; x=26.4 \pm 19.7 \\
(12-48 \text { months })\end{array}$ & $\begin{array}{l}3 \text { (9\%); } x=16.7 \pm 2.5 \\
\quad(14-17 \text { months })\end{array}$ \\
\hline Primary response failure (up to 3 months) & $7(12.7 \%)^{*}$ & $3(9 \%)^{*}$ \\
\hline Secondary response failure & $\begin{array}{l}19 \text { (34.5\%); after } x=28 \pm 22.3 \\
\text { (9-106) months }\end{array}$ & $\begin{array}{l}2(6.1 \%) \\
\text { after } 15 \text { and } 24 \text { months }\end{array}$ \\
\hline Remissions and recurrences & $\begin{array}{c}9(16.4 \%) ; x=6.4 \pm 6.7^{\star \star} \\
(1-20) \text { months }\end{array}$ & $\begin{array}{c}10(30.3 \%)^{\star \star} \\
x=4.6 \pm 3.3 \\
(2-12) \text { months }\end{array}$ \\
\hline $\begin{array}{l}\text { Infection as the cause for discontinuation } \\
\text { of therapy }\end{array}$ & $\begin{array}{l}2 \text { (3.6\%); after } 1 \text { and after } 2 \text { months } \\
\text { (respiratory tract, urinary tract) }\end{array}$ & $\begin{array}{c}1-\text { TB after } 6 \text { months; } \\
\text { (second-line therapy following } \\
\text { infliximab) }\end{array}$ \\
\hline $\begin{array}{l}\text { Skin lesions as the cause for discontinuation } \\
\text { of therapy }\end{array}$ & $\begin{array}{l}3 \text { (5.5\%); after } 1 \text { dose; after } 1 \\
\text { and after } 2 \text { months }\end{array}$ & 1 - after 6 weeks of treatment \\
\hline
\end{tabular}

This table contains mean values $(x) \pm$ standard deviations $(S D)$; ${ }^{*}$ statistically non-significant difference $(p=0.6055)-$ proportion test; ${ }^{* *}$ statistically significant difference $(p<0.05)$ - proportion test

drug-free remission for a mean period of 4.6 months; some patients experienced a significant increase in disease activity, which required the reintroduction of the same medication, after an interval of only one month (Table II).

A similar percentage of patients with RA and with AS ( $9 \%$ of patients) achieved and sustained remission for a peri- od exceeding 12 months without biological drug administration, with continued synthetic DMARD (patients with RA) or NSAID (patients with AS) therapy. There were no significant differences in the incidence of primary lack of efficacy of ETA therapy between the groups of patients with RA and with AS (12.7\% vs. 9\%). Secondary loss of response 
to long-term ETA treatment was observed in $1 / 3$ of patients after, on average, 28 months of treatment. This group included one patient who developed secondary failure after 106 months of treatment (prior to his enrolment in the therapeutic program the patient had been treated outside of our facility). Secondary failure in AS patients was observed less frequently (Table II); however, the significantly shorter follow-up period for patients with AS (30 months) made comparison between the groups of RA and AS patients difficult in this aspect.

Adverse effects that resulted in discontinuation of ETA therapy occurred in 3 patients with RA and in 1 patient with AS (4/88 patients $-4.5 \%)$. Adverse symptoms occurred in a very early stage of treatment (the initial two months). Serious infections (involving the respiratory and urinary tracts) which led to the withdrawal of treatment occurred in 2 patients with RA, also in an early stage of therapy. After 6 months of treatment with ETA, one female AS patient developed tuberculosis. However, this patient had previously been treated for over a year with infliximab; treatment had been discontinued because of symptoms of intolerance.

\section{Discussion}

Studies assessing long-term efficacy and tolerance of ETA in patients with RA, JAA and AS indicate that it has a very good therapeutic action [1, 8-11]. It has been proven that administration of ETA in combination with MTX in RA significantly reduces the progression of radiological lesions [8].

The most frequent adverse effects reported during ETA therapy include injection-site allergic reactions and infections - which typically have a mild course [1, 3, 4, 10]. Data on the course and results of long-term treatment of patients with chronic inflammatory diseases of the joints (RA and AS) are available mainly from clinical studies which are, unfortunately, conducted only on selected groups of patients. More comprehensive information on the results of biological treatments in routine clinical practice is available primarily from national registers [3, 8-15]. To date, there is only one register in Poland, for patients with JIA treated with biological drugs [14]. Regulations governing the implementation of TPS create a situation in which the results of long-term treatment using biological drugs cannot be compared with data from other countries' registers. However, since the therapeutic program is based on international recommendations [16-18], the immediate results of treatment may be comparable, although it is necessary to make allowances for differences arising from the requirements and restrictions governing therapeutic programs in our country. Our observations show that patients in Poland begin treatment with biological drugs in a period of very high disease activity, as regards both RA and AS (DAS28 5.9; BASDAI 7; Table II). Our observations show that approx. $9 \%$ of patients have a likelihood of long-term remission (> 12 months with no biological drug treatment) with continued standard DMARD treatment in RA and NSAID therapy in AS. These data are consistent with published data, derived from registers $[14,16]$. The percentage of patients with primary lack of efficacy of ETA therapy (lack of adequate response to treatment during the first 3 months of therapy) in our group of patients was similar to registry data, amounting to $12.7 \%$ in RA patients and $9 \%$ in patients with AS.

The observations regarding development of secondary loss of response to treatment, present in approx. 1/3 of RA patients after almost 3 years of therapy, are very interesting. In making this assessment one must take into account the fact that, as a result of the requirements of the therapeutic program, treatment had been temporarily interrupted in the majority of these patients once they achieved remission or low disease activity.

In patients with RA, recurrences of disease activity that necessitated reintroduction of the medication that had produced remission occurred, on average, after 6 months. Furthermore, there was a group of patients who experienced recurrences as early as 4 weeks after the withdrawal of treatment. Recurrences of disease activity in patients with AS after having achieved remission occurred, on average, after 4 months, i.e. after a shorter period than in RA. Infections and allergic skin reactions that led to treatment discontinuation were relatively rare and occurred in an early stage of treatment.

\section{Conclusions}

Etanercept is a safe and effective medication for treating active RA and AS. Primary failure of ETA therapy is relatively rare and occurs with similar frequency in patients with RA and AS. Secondary loss of efficacy of therapy is the cause of discontinuation of treatment in approx. 1/3 of RA patients - on average after 28 months of treatment - though this period varies from patient to patient. Regulations governing the therapeutic program permit initiation of treatment with biological drugs in patients with RA and AS in periods of high disease activity and stipulate that therapy must be withdrawn after achieving low disease activity or remission, which may affect treatment results.

The author declares no conflict of interest and no funding.

\section{References}

1. Kucharz E. Etanercept - budowa, farmakologia, farmakokinetyka, interakcje. W: Enbrel-zastosowanie kliniczne. Wiland P (red.). Wydawnictwo Medyczne Górnicki, Wrocław 2012; 17-21.

2. Zhou $\mathrm{H}$. Clinical pharmacokinetics of etanercept: a fully humanized soluble recombinant tumor necrosis receptor fusion protein. J Clin Pharmacol 2005; 45: 490-497. 
3. Dhillon S, Lyseng-Williamson KA, Scott LJ. Etanercept: a review of its use in the management of rheumatoid arthritis. Drugs 2007; 67: 1211-1241.

4. Charakterystyka produktu leczniczego (ChPL) Enbrel, 2010.

5. Śliwczyński A, Kruszewski R, Binkowski J i wsp. Finansowanie leczenia lekami biologicznymi chorych na reumatoidalne i młodzieńcze idiopatyczne zapalenie stawów w ramach programów zdrowotnych NFZ w latach 2004-2008. Reumatologia 2010; 48: 14-24.

6. Wiland P, Maciążek-Chyra B. Stan reumatologii w Polsce w 2012 roku. Reumatologia 2012; 50: 263-275.

7. Programy lekowe. Obwieszczenie Ministra Zdrowia z dnia 28 czerwca 2012 r. w sprawie wykazu refundowanych leków, środków spożywczych specjalnego przeznaczenia żywieniowego oraz wyrobów medycznych na dzień 1 lipca 2012 r. (załączniki: B.33, B.35, B.36).

8. Emery P, Breedveld F, van der Heijde D, et al. Two-year clinical and radiographic results with combination etanercept-methotrexate therapy versus monotherapy in early rheumatoid arthritis a two-year, double-blind, randomized study. Arthritis Rheum 2010; 62: 674-682.

9. Anis A, Zhang W, Emery P, et al. The effect of etanercept on work productivity in patients with early active rheumatoid arthritis: results from the COMET study. Rheumatology 2009; 48: 1283 1289.

10. Braun J, van der Horst-Bruinsma IE, Huang F, et al. Clinical efficacy and safety of etanercept versus sulfasalazine in patients with ankylosing spondylitis. Arthritis Rheum 2011; 63: 1543-1551.

11. Pavelka K, Forejtová S, Stolfa J, et al. Anti-TNF therapy of ankylosing spondylitis in clinical practice. Results from the Czech national registry ATTRA. Clin Exp Rheumatol 2009; 27: 958-963.

12. Pavelka K, Fojtiková M, Hejduk K. Efficacy of the first and subsequent courses of anti-TNF therapy in patients with ankylosing spondylitis - results from the Czech national Register ATTRA. Reumatologia 2012; 50: 294-306.

13. Elkayam O, Pavelka K. Biologic registries in rheumatology: lessons learned and expectations for the future. Autoimmun Rev 2012; 12: 329-336.

14. Żuber Z, Rutkowska-Sak, Postępski J, et al. Etanercept treatment in juvenile idiopathic arthritis: the Polish registry. Med Sci Monit 2011; 7: SR35-SR42.

15. Raciborski F, Nyczaj K, Głuszko P i wsp. Rejestry medyczne w reumatologii: czy w Polsce potrzebny jest rejestr reumatologiczny? Reumatologia 2012; 50: 416-424.

16. Smolen JS, Landewé R, Breedveld FC, et al. EULAR recommendations for management of rheumatoid arthritis with syntetic and biological diseases-modifying antirheumatic drugs. Ann Rheum Dis 2010; 69: 964-975.

17. Smolen JS, Aletaha D, Bijlsma JW, et al. Treating rheumatoid arthritis to target: recommendations of an international task force. Ann Rheum Dis 2010; 69: 631-637.

18. Singh JA, Furst DE, Bharat A, et al. 2012 update of the 2008 American College of Rheumatology recommendations for the use of disease-modifying antirheumatic drugs and biologic agents in the treatment of rheumatoid arthritis. Arthritis Care Res (Hoboken) 2012; 64: 625-639. 